\title{
Tibetan Herders' Life Satisfaction and Determinants under the Pastureland Rehabilitation Program: A Case Study of Maduo County, China
}

\author{
Cuizhen Xia ${ }^{1,2}$, Lihua Zhou ${ }^{1,2, *}$, Ya Wang ${ }^{3}$ and Xiaodong Pei ${ }^{1,2}$ (D) \\ 1 Institutes of Science and Development, Chinese Academy of Sciences, Beijing 100190, China; \\ xiacuizhen@1zb.ac.cn (C.X.); xdpeiucas@126.com (X.P.) \\ 2 School of Public Policy and Management, University of Chinese Academy of Sciences, Beijing 100049, China \\ 3 Northwest Institute of Eco-Environment and Resources, Chinese Academy of Sciences, \\ Lanzhou 730000,China; wy_2005@yeah.net \\ * Correspondence: lhzhou@casisd.cn
}

Citation: Xia, C.; Zhou, L.; Wang, Y.; Pei, X. Tibetan Herders' Life Satisfaction and Determinants under the Pastureland Rehabilitation Program: A Case Study of Maduo County, China. Sustainability 2022, 14 2381. https://doi.org/10.3390/ su14042381

Academic Editor: Yu Cao

Received: 31 December 2021

Accepted: 10 February 2022

Published: 19 February 2022

Publisher's Note: MDPI stays neutral with regard to jurisdictional claims in published maps and institutional affiliations.

Copyright: (C) 2022 by the authors. Licensee MDPI, Basel, Switzerland. This article is an open access article distributed under the terms and conditions of the Creative Commons Attribution (CC BY) license (https:// creativecommons.org/licenses/by/ $4.0 /)$.

\begin{abstract}
The Pastureland Rehabilitation Program (PRP) has been implemented for nearly 20 years, and the lives of herders in different regions have been affected to varying degrees. The level of people's well-being could measure the success of policy. Taking Maduo County as an example, the life satisfaction of 266 Tibetan herders was investigated through a participatory questionnaire survey in July 2021. Multiple linear regression and optimal scale regression were constructed to analyze the impact of the satisfaction of different aspects of life and PRP on life satisfaction, respectively. The results show that the herders in Maduo County had relative high satisfaction in various aspects of life and overall life, and leisure and consumption were important aspects influencing life satisfaction. The relative living standard, the difficulty in borrowing and the quality of government services had a significant positive impact on herders' life satisfaction. Occupation and migration location also led to the significant differences of life satisfaction. However, the income changes caused by PRP and subsidy levels did not show a significant impact. We discussed the particularity of Maduo County and suggested that more attention should be paid to the improvement of the social environment such as wealth disparity, channels of assistance, working environment, and the effective assistance formulated according to the demands of different groups needs to be optimized continuously, so as to enhance the self-development ability of herders.
\end{abstract}

Keywords: life satisfaction; herder; Maduo; Pastureland Rehabilitation Program; subjective well-being

\section{Introduction}

The pursuit of well-being is as old as human history [1]. Life satisfaction is one of the most important human values [2], an important part of subjective well-being [3,4], and a powerful supplement to the evaluation of an individual's actual state in addition to objective economic and social indicators [5,6]. Its reliability as an approximate estimate of personal utility has been verified in decades of research [7]. Individual well-being today has been also regarded as an indicator of social progress [8,9], and using people's self-reported life satisfaction to assess the effectiveness of governance has been prevalent around the world $[10,11]$. Life satisfaction surveys have been often used for various groups in different regions, and the reasons for the differences in satisfaction have been also deeply analyzed to find ways to improve human well-being [12-16]. Many studies have shown that in addition to people's own characteristics, social and economic factors can also affect well-being, which may be influenced by policy makers [9].

As one of the typically comprehensive ecological restoration projects in China, the Pastureland Rehabilitation Program (PRP) was started in 2003 and covered almost all grassland areas in China, which account for $41.7 \%$ of the country's land area [17]. The 
project aimed to curb grassland degradation and restore the function of grassland ecosystem through fence construction, resowing, grazing prohibition, rest grazing, rotational grazing, ecological compensation and other measures. However, due to the strict restrictions on the use of grassland, the lives of herders whose livelihood rely heavily on grassland have been seriously changed, which further affects their well-being [18]. The policy support and the adaptability of herders jointly determine the impact of the PRP on the overall wellbeing of herders' families, and the loss of well-being often leads to many illegal grazing behaviors, such as grazing in grazing-prohibited areas or times, or maintaining a number of livestock exceeding the specified standard [19,20]. Ensuring the well-being of herders is considered to be a solution to alleviate the contradictions between herders and government and promote ecological protection [21,22].

The Three-River Headwaters Region, located in the interior of the Qinghai-Tibetan Plateau, has a particularly critical ecological status because it breeds the Yangtze River, Yellow River, and Lancang River, the three most important rivers to China and Southeast Asian countries. There, alpine grasslands and meadows are the main vegetation types, and nomadism has always been the traditional livelihood of local Tibetans. The central government always gives priority to the ecological quality of the region. Therefore, in the early stage of PRP, a large area of grazing prohibition and ecological immigration were implemented here. How to properly resettle local herders and ensure their livelihood has become a key issue that the government must consider. It has been nearly 20 years since the project was implemented; what is the living condition of the herders in the area, and is their well-being guaranteed? What other changes can the government make to improve well-being? With Maduo County, the source of the Yellow River, as a typical area, we investigated the satisfaction of local herders in various aspects of life and overall life satisfaction through field research, and used the multiple linear regression and optimal scale regression models to analyze the determinants of life satisfaction. Through the identification of the impact path of PRP on the herders' life satisfaction, the optimization suggestions of the program are put forward to improve herders' well-being.

\section{Literature Review}

Life satisfaction is a subjective evaluation of the life quality made by individuals based on their own standards [23,24]. Previous studies have indicated that recent experiences (accidents, death in family and other emergencies), factors of short and medium term (emotional fluctuations, housing, and marital status, etc.) and very long-term factors (personality and emotional intelligence, etc.) will affect self-reported life satisfaction [6]. Due to the differences of each person's personality, experience, and external environment, the research results on the determinants of life satisfaction are rich and complicated. Economic factors such as income and relative income, employment, and noneconomic or underlying factors such as age, gender, marital, health, education, religion, and social and political institutions have been found to be significantly associated with life satisfaction $[25,26]$.

Three theories could be used to explain the differences in satisfaction, namely need and goal satisfaction theories, process or activity theories, genetic and personality predisposition theories [26,27]. The first theory states that people have high life satisfaction when their needs are met. According to Maslow's Hierarchy of Needs theory, people first need to meet physiological needs, which require adequate availability of basic needs such as food, housing, fuel, etc. [28]. Multiple comparisons theory also offers another explanation of life satisfaction [29]. This theory argues that life satisfaction depends on the individual's comparison with various standards, which may be related to social standards, the level of people around, personal desires and goals, and past experiences [6,30].

In ecologically fragile areas, the guarantee of residents' well-being has become more complicated due to the pursuit of ecological protection. In the implementation area of PRP, the external environment and herders' experience have changed under the intervention of various measures, which may further affect herders' perception and life satisfaction (shown in the Table 1). Grazing prohibition has caused herders to lose their available pastures, and 
forage-livestock balance has stipulated the maximum number of livestock that herders can raise and the time available for grazing. After immigration, herders without other skills have found it difficult to find new jobs, resulting in their increased dependence on government subsidies. In the past 20 years, household income, livelihood adjustments and adaptation, and compensation standard under the PRP have received extensive attention from scholars [31-34].

Table 1. Measures and impact on herders of Pastureland Rehabilitation Program $[18,19,35,36]$.

\begin{tabular}{|c|c|c|}
\hline Measure & Specific Measure & Impact on Herders \\
\hline \multirow[t]{3}{*}{ Main measures } & Grazing prohibition & Pasture would be forbidden to use \\
\hline & Forage-livestock balance & $\begin{array}{l}\text { The number of livestock and } \\
\text { grazing time would be limited }\end{array}$ \\
\hline & Restoration of degraded grassland & $\begin{array}{l}\text { Degraded grassland shall be } \\
\text { restored by government }\end{array}$ \\
\hline \multirow[t]{5}{*}{ Supporting measures } & Fence construction & $\begin{array}{l}\text { Each household's pasture would } \\
\text { be spatially separated }\end{array}$ \\
\hline & Livestock shed construction & Livestock could be raised in sheds \\
\hline & Artificial grassland construction & $\begin{array}{l}\text { The shortage of forage } \\
\text { could be alleviated }\end{array}$ \\
\hline & Ecological migration & $\begin{array}{l}\text { Herders in key protected area } \\
\text { would be relocated }\end{array}$ \\
\hline & Ecological compensation & $\begin{array}{l}\text { The economic losses of herders } \\
\text { would be partially compensated }\end{array}$ \\
\hline
\end{tabular}

In the implementation area of the PRP, such as Ningxia, Gansu, Inner Mongolia, Qinghai, and other places, many studies have focused on the satisfaction of herders with individual measures such as ecological compensation and grazing prohibition. The results have showed that the policy satisfaction of herders and influencing factors in different regions were different $[21,22]$. When considering the influencing factors, scholars tend to choose variables from personal characteristics, family capital, environmental factors, policy perception and so on. In terms of objective factors, herders' family size, education level, livestock number, income and expenditure, and social frequency significantly may significantly affect farmers' or herders' policy satisfaction; in terms of subjective factors, relative income, ecological protection awareness, environmental satisfaction, social welfare satisfaction and subjective evaluation of compensation standard may significantly affect farmers' or herders' policy satisfaction $[37,38]$. Although individual policy satisfaction of herders may further affect their overall well-being [39], focusing on a single measure may not fully reflect the PRP's impact on well-being, and the evaluation of satisfaction with a single measure may also contain the impacts of other measures. Therefore, taking the overall life satisfaction of the herders under the background of PRP as the research object, and determining the impact factors according to the way the grazing-returning project affects the livelihoods of the herders, could better illustrate the PRP's impact on the herders.

\section{Materials and Methods}

\subsection{Overview of the Study Area and PRP}

Maduo County is located in the northeastern part of the Qinghai-Tibet Plateau, at the northern foot of the Bayan Har Mountain, between $96^{\circ} 50^{\prime} \mathrm{E}-99^{\circ} 20^{\prime} \mathrm{E}, 33^{\circ} 50^{\prime} \mathrm{N}-35^{\circ} 40^{\prime} \mathrm{N}$. The administrative division is subordinate to the Guoluo Tibetan Autonomous Prefecture in Qinghai Province, and is the core component of Sanjiangyuan National Park. The average altitude is above $4200 \mathrm{~m}$, and the terrain is relatively flat, with many low mountains, wide valleys and lake basins. It belongs to an alpine grassland climate, with a cold season for more than 10 months in a year. The annual average temperature is $-4.1^{\circ} \mathrm{C}$, and the annual precipitation is about $303.9 \mathrm{~mm}$, mostly from May to June. There are dense rivers and numerous lakes, accounting for $43 \%$ of the total runoff of the Yellow River Basin. The 
county has a total area of about $25,253 \mathrm{~km}^{2}$, and the usable grassland area accounts for about $90 \%$ of the county's total area.

Maduo County currently administers 4 townships, namely Huanghe Town, Zalenghu Town, Huashixia Town and Machali Town. It has the smallest prefectural population in Qinhai Province, with a total population of 144,490 , of which the Tibetan population accounts for more than $90 \%$. Animal husbandry is the local pillar industry. In the 1980s, herders' per capita net income in Maduo County once ranked first in the country [40]. However, due to the severe deterioration of the ecological environment in the 1990s, the development of local animal husbandry was hindered. After the establishment of the reserve and implementation of ecological restoration projects since 2000, local animal husbandry has been developing slowly due to strict protection restrictions, and it became a national key county for poverty alleviation in 2011. At present, the income of local herders is mainly based on policy subsidies, animal husbandry, and other jobs. In 2018, the annual per capita income of residents was CNY 7401, of which policy subsidies accounted for about $57 \%$ and animal husbandry income accounted for about $40 \%$.

The PRP includes a series of specific measures. In order to reduce the livestock number on grassland, complete grazing prohibition and forage-livestock balance, as well as some supporting policies, such as ecological compensation and ecological immigration, fence construction, livestock barn construction, grass storage cellar construction, etc. are included; in order to promote the restoration of grassland vegetation, reseeding grass seed, artificial grassland construction, restoration of black beach and sandy land, prevention and control of poisonous grass and plateau pika are all included. In 2003, the government of Qinghai Province began to implement the PRP on $94.5 \%$ of the province' s grasslands, covering an area of $3.45 \times 10^{5} \mathrm{~km}^{2}$. Due to its geographical location at the source of the Yellow River, Maduo County has a wide grazing prohibition area. In 2019, the grazing prohibition area was about $1.67 \mathrm{~km}^{2}$, and the forage-livestock balance area was $0.58 \mathrm{~km}^{2}$, accounting for $74.22 \%$ and $25.78 \%$ of the total usable grassland area, respectively. There have been two large-scale migrations. The first time was the ecological migration from 2004 to 2007, which relocated about 2022 herders to collective villages, accounting for about a quarter of the population at that year. The second time was the herders' relocation for poverty alleviation from 2016, where new houses were built around the county town for 4473 herders, covering more than one third of the population in that year.

At present, the compensation standard for grazing prohibition in Maduo County is CNY $4.1 / \mathrm{mu}$ (one mu is approximately $666.67 \mathrm{~m}^{2}$ ), and that for forage-livestock is CNY $2.5 / \mathrm{mu}$. Due to the change of family population over the years, the per capita grassland area has become no longer balanced. Therefore, the local government has coordinated various subsidies from the superior government according to the actual situation. The existing subsidy system includes grassland subsidies (approximately CNY 9000 per person per year), ecological inspector subsidies (approximately CNY 21,600 per year), and groups in difficulties (people under the age of 16 and over the age of 55, CNY 5600 per year), subsistence allowance (about CNY 3600 a year), pensions of CNY 200 a month, etc., and the subsidies received by each family vary according to their family situation.

\subsection{Data Source}

Using the participatory rural evaluation method, the research group travelled to Maduo County twice in August 2020 and July 2021. The first time was a preinvestigation, mainly to understand the implementation of PRP and other policy arrangements in Maduo County. For the second time, a large-scale survey of herders was officially carried out. Due to language barriers, we designed a structured questionnaire and hired and trained four local college students to assist in filling out the questionnaire (see blank informed consent in Appendix A). Using the stratified random sampling method, we successively investigated herders in Guoluo New Village, Tongde County, Hainan Tibetan Autonomous Prefecture (an immigrant village founded in 2006), Heyuan New Village, Maqin County, Guoluo Tibetan Autonomous Prefecture (an immigrant village founded in 2004), Machali 
Village, Maduo County, Guoluo Tibetan Autonomous Prefecture (an immigrant village founded in 2007). Although the herders settle in other administrative districts, Guoluo New Village is under the management of Huanghe Township, and Heyuan New Village is under the management of Zalinghu Township. Due to the earthquake on 22 May 2021, many herders in different towns were intensively settled to receive government assistance, so we were able to investigate at various resettlement sites. Figure 1 showed several major survey points, and random surveys scattered over grasslands were not identified. Finally, a total of 266 respondents filled out the questionnaire. Among them, the herders in Huanghe Town, Zhalinghu Town, Machali Town, and Huashixia Town accounted for 36.09\%, 31.20\%, $20.30 \%$, and $12.41 \%$ respectively. In total, $28.57 \%$ were intercity immigrants, $25.56 \%$ were intercounty immigrants, and $45.86 \%$ were local settlers.

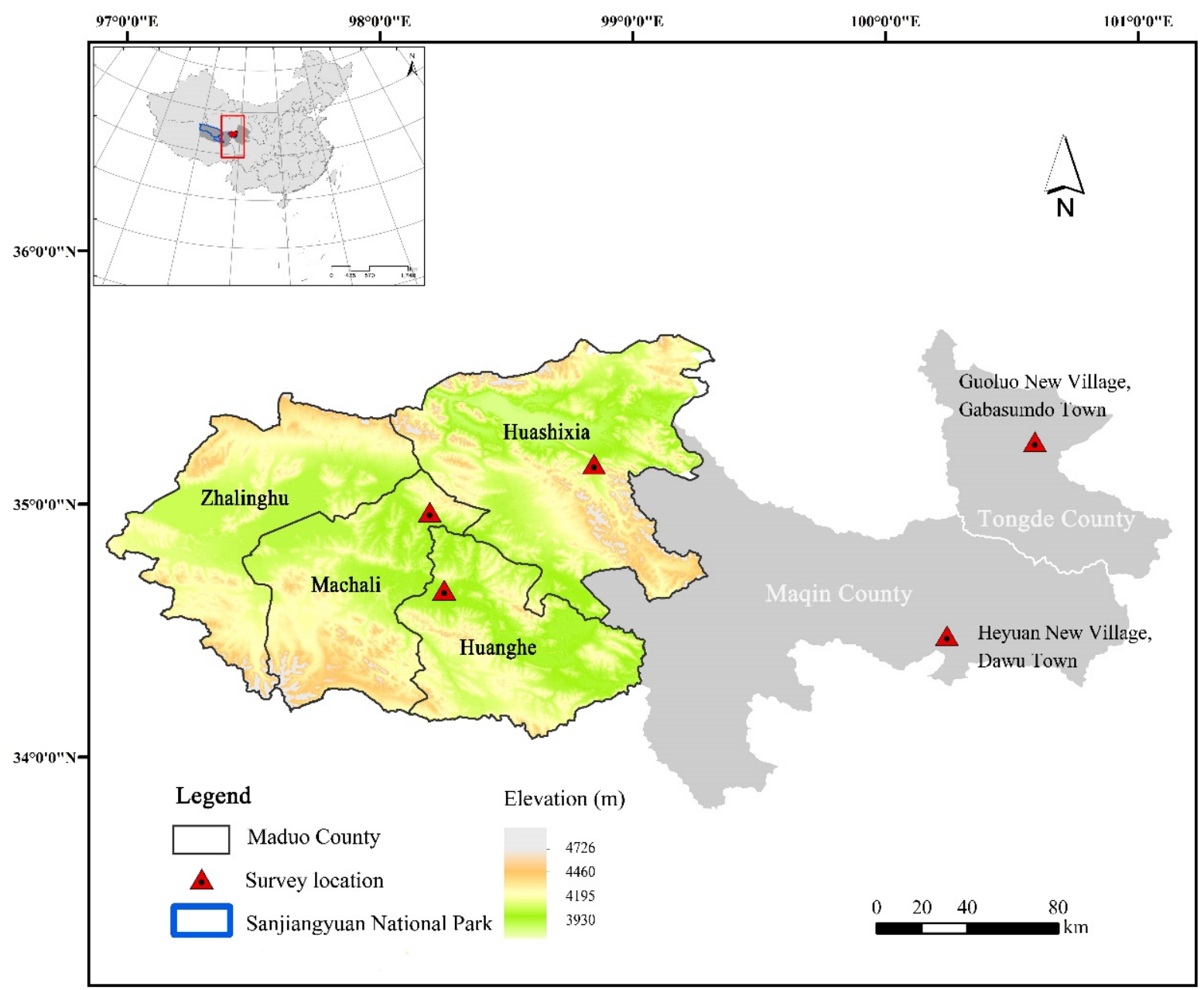

Figure 1. Location of research area.

\subsection{Research Methods}

In recent decades, self-reported life satisfaction has become an available indicator to measure quality of life [9]. Although a multi-item scale has higher validity and reliability $[5,41]$, the one-dimensional satisfaction scale has also been widely used in measuring overall life satisfaction or satisfaction in one field [10,11,27]. Taking life satisfaction as the dependent variable, a single scale of "are you satisfied with your current life?" was designed to measure the life satisfaction of herders in Maduo County from very dissatisfied to very satisfied according to the division of Likert's five-level scale. In addition, the satisfaction of herders in other main areas of life was investigated, including housing, medical treatment, education, work, income, consumption, leisure, neighborhood, etc. 
Multiple linear regression could be used to analyze the relationship between the indicators in the subjective evaluation scale [11]. In our study, the model was used to analyze the impact of satisfaction in different aspects on overall life satisfaction, in order to determine which aspects of life have a significant association with life satisfaction, and the degree of their respective effects. Stepwise regression was adopted to directly screen out the key life aspects that have significant impacts on overall life satisfaction. The principle of this method is to recalculate significance of the substituted independent variables after introducing each new independent variable, and judge whether it is necessary to continue to remain them in the equation. After repeated introduction and elimination of independent variables until no new significant variables could be introduced or removed, an optimal explanatory model was finally obtained, and the independent variables remaining in the model were all ones that have a significant effect on the dependent variable.

In order to explore the influencing factors of herders' life satisfaction under the implementation of PRP, three-dimensional influencing factors were listed according to the actual situation of herders in Maduo County and previous research (see Table 2). The first dimension was the demographic characteristics of herders and the socioeconomic characteristics of their families, mainly involving the respondents' gender, age, education, occupation, income, etc.; second, we paid attention to the impact of the natural and social environments on herders' life satisfaction. In terms of natural environment, herders' evaluation of natural environment quality was selected as the representative indicator of the impact of the natural environment on their lives; in terms of social environment, we focused on the support for herders' livelihood in three aspects-herders' ability, social relations, and government assistance - and selected relative living standard, difficulty in borrowing, market convenience, and government service satisfaction as representative indicators. The difficulty in borrowing reflects the possibility of herders obtaining external assistance in case of economic difficulties, and the market convenience reflects the difficulty of herders in livestock trading, working, and self-employment. Third, we paid special attention to whether the direct impact of the PRP project on herders would affect herders' life satisfaction, which mainly involved three aspects, those being immigration, income, and grassland restoration, with settlement site, herders' perception of income impact, subsidy level, and revegetation effect as the specific indicators. The assignment of all indicators is shown in Table 2. Based on previous research, we hypothesized that the availability of social support may be positively correlated with life satisfaction, because it would meet herders' needs of safety. The project of PRP may have a negative impact on the life satisfaction of herders, which may be due to the reduction of animal husbandry income after grazing prohibition and the maladjustment after the change of their traditional lifestyle.

Since the dependent variable and most of independent variables are subjectively ordinal multicategorical variables but not precise quantitative variables, traditional linear regression could not accurately reflect the actual meaning of those variables. Otherwise, in the logistic regression model, dummy variables should be set for multilevel independent variables, respectively. In our study, the model results may struggle to accurately reflect the actual situation due to too many categories of independent variables and the small number of samples after setting dummy variables. Finally, we found that it is more appropriate to select the optimal scale regression model.

Optimal scaling regression is a new program after SPSS11.0 developed by DTSS research group of Leiden University in the Netherlands (The version we use is SPSS 27.0, released by IBM in Armonk, NY, USA). This method breaks through the limitation of categorical variables on model selection. In the analysis, according to the influence of each level of each independent variable on the dependent variable, a nonlinear transformation method is used to convert the values of each level of the original categorical variables on the premise that the linear relations of transformed variables are maintained, and the converted values are used to replace the original values for model construction. After repeated iterations, the best model is finally constructed. The difference between the converted values approximately indicates the difference in the influence degree of different 
levels of independent variables on the dependent variable. A large difference in two values indicates a large difference in the influence between corresponding levels. In this way, the differences between various levels can be quickly found and the possible irrationality of the original assignment can be avoided. The model structure is similar to the general linear regression, as shown below. $x_{i}$ represents the independent variable, $\varepsilon_{i}$ represents the random error.

$$
y_{i}=\beta_{0}+\beta_{i} x_{i}+\varepsilon_{i}
$$

Table 2. List of independent variables.

\begin{tabular}{|c|c|c|}
\hline Dimension & Variable Name & Variable Assignment \\
\hline \multirow{8}{*}{$\begin{array}{l}\text { Personal } \\
\text { characteristics }\end{array}$} & Gender & Male $=1 ;$ Female $=2$ \\
\hline & Age & Quantitative variable \\
\hline & & Illiterate $=1 ;$ Primary school $=2$ \\
\hline & Education & Junior high school = 3 \\
\hline & & High school $=4 ;$ College or above $=5$ \\
\hline & Occupation & Unemployed $=1$; Independent employment $=2$; \\
\hline & & Employed by government $=3$ \\
\hline & Willingness to change & $\begin{array}{l}\text { Don't want to change at all }=1 ; \text { Obedience to } \\
\text { government arrangement }=2 ; \\
\text { Depending on the situation }=3 ; \\
\text { Want to change }=4 ; \text { Eager to change }=5\end{array}$ \\
\hline \multirow{5}{*}{$\begin{array}{l}\text { Family } \\
\text { characteristics }\end{array}$} & Health & Incapacity $=1 ;$ Poor $=2 ;$ Medium $=3 ;$ \\
\hline & Jivectork retention & Good $=4 ;$ Excellent $=5$ \\
\hline & Livestock retention & $\begin{array}{l}\text { No }=1 ; \text { Yes }=2 \\
\text { Less than } C N Y 30 \text { thousand }=1 ; \text { CNY } 30-50\end{array}$ \\
\hline & Annual income & $\begin{array}{l}\text { thousand = } 2 \text {; CNY } 50-100 \text { thousand }=3 \\
\text { Over CNY } 100 \text { thousand }=4\end{array}$ \\
\hline & Natural environment & $\begin{array}{l}\text { Very poor }=1 ; \text { Poor }=2 ; \text { Fair }=3 ; \\
\text { Good }=4 ; \text { Very good }=5\end{array}$ \\
\hline \multirow[t]{4}{*}{$\begin{array}{l}\text { Perception of } \\
\text { the environment }\end{array}$} & Relative living standard & $\begin{array}{l}\text { Lower }=1 ; \text { Lower-middle }=2 ; \text { Middle }=3 ; \\
\text { Upper-middle }=4 ; \text { Upper }=5\end{array}$ \\
\hline & Difficulty in borrowing & $\begin{array}{l}\text { Very difficult }=1 ; \text { Relatively difficult }=2 \text {; Depending } \\
\text { on the situation }=3 ; \\
\text { Relatively easy }=4 ; \text { Very easy }=5\end{array}$ \\
\hline & Market convenience & $\begin{array}{l}\text { Very inconvenient }=1 ; \text { Inconvenient }=2 ; \text { Fair }=3 \text {; } \\
\text { Convenient }=4 ; \text { Very convenient }=5\end{array}$ \\
\hline & Government services & $\begin{array}{l}\text { Very dissatisfied }=1 ; \text { Dissatisfied }=2 ; \text { Neither } \\
\text { satisfied nor dissatisfied }=3 ; \\
\text { Satisfied }=4 ; \text { Very satisfied }=5\end{array}$ \\
\hline \multirow[t]{4}{*}{ Impact of PRP } & Immigration & $\begin{array}{l}\text { Trans-city migration }=1 ; \text { Trans-county migration }=2 ; \\
\text { Local residence }=3\end{array}$ \\
\hline & Income change & $\begin{array}{l}\text { Decrease a lot }=1 ; \text { Decrease a little }=2 ; \text { No change }=3 ; \\
\text { Increased a little }=4 ; \text { Increase a lot }=5\end{array}$ \\
\hline & Subsidy level & $\begin{array}{l}\text { Very few }=1 ; \text { few }=2 ; \text { Appropriate }=3 ; \\
\text { Many }=4 ; \text { Too many }=5\end{array}$ \\
\hline & Grassland restoration & $\begin{array}{l}\text { Very poor }=1 ; \text { Poor }=2 ; \text { Fair }=3 ; \\
\text { Good }=4 ; \text { Very good }=5\end{array}$ \\
\hline
\end{tabular}

\section{Results}

\subsection{Descriptive Analysis}

The proportion of some basic characteristics of the respondents was presented in Table 3 . Of all respondents, men and women accounted for $55 \%$ and $45 \%$, respectively, $81.95 \%$ were between 20 and 60 years old. In total, $76.69 \%$ of respondents had never attended school, indicating that the heads of households in this area generally have a low level of education, which may have a negative impact on family development. The households with a large number of livestock (more than 10) accounted for only 8.64\% of the surveyed samples, and most households did not have livestock. One reason for this result may be that many herders have abandoned livestock breeding or converted their livestock into cooperative as shares after the large-scale grazing prohibition in Maduo County; the other one may be that the time of the survey coincided with herders who had a large number of livestock moving to a remote summer pasture, making it difficult to find more samples. In terms of employment, only $31.95 \%$ of households had their own income channels, such 
as grazing, formal work, part-time jobs, self-employed entrepreneurs. Nearly $50 \%$ of herders were only engaged in positions provided by the government, such as ecological inspector and cleaner. In addition, nearly $20 \%$ of households had no work. In terms of household income, the proportions from high to low were CNY 30 to 50 thousand (43.99\%), CNY 50 to 100 thousand (32.71\%), less than CNY 30 thousand (16.92\%), and greater than CNY 100 thousand (5.26\%). A total of $62.93 \%$ of herders believed that expenditure was greater than income, and food and medical care are the main expenses. Only $9.05 \%$ of households felt income greater than expenditure. It could be seen that the economic base of herders in Maduo County is weak. The livelihood of most households relies on cash subsidies and job provided by government, and their consumption is mainly concentrated on daily necessities, and there is a lack of reserves to cope with risks. This section may be divided by subheadings. It should provide a concise and precise description of the experimental results, their interpretation, as well as the experimental conclusions that can be drawn.

Table 3. Basic characteristics of herders' livelihood.

\begin{tabular}{|c|c|c|c|c|c|}
\hline Category & Types & Proportion & Category & Types & Proportion \\
\hline \multirow{2}{*}{ Gender } & Male & $55.26 \%$ & \multirow{2}{*}{$\begin{array}{l}\text { Livestock } \\
\text { retention }\end{array}$} & No & $91.35 \%$ \\
\hline & Female & $44.74 \%$ & & Yes & $8.65 \%$ \\
\hline \multirow{4}{*}{ Age } & $<20$ & $4.14 \%$ & \multirow{4}{*}{ Occupation } & Unemployed & $19.55 \%$ \\
\hline & $20-40$ & $36.84 \%$ & & Independent employment & $31.95 \%$ \\
\hline & $40-60$ & $45.11 \%$ & & Employed by government & $48.50 \%$ \\
\hline & $>60$ & $13.91 \%$ & & Less than CNY 30 thousand & $16.92 \%$ \\
\hline \multirow{5}{*}{ Education } & Illiterate & $76.69 \%$ & \multirow{3}{*}{ Annual income } & CNY 30 50 thousand & $43.98 \%$ \\
\hline & Primary school & $10.90 \%$ & & CNY 50 100 thousand & $32.71 \%$ \\
\hline & Junior high school & $5.64 \%$ & & $\begin{array}{l}\text { Over CNY } 100 \text { thousand } \\
\text { Expenditure exceeds income }\end{array}$ & $\begin{array}{l}5.26 \% \\
62.93 \%\end{array}$ \\
\hline & High school & $3.76 \%$ & \multirow[t]{2}{*}{ Balanced budget } & Expenditure equals income & $28.02 \%$ \\
\hline & College or above & $3.01 \%$ & & Income exceeds expenditure & $9.05 \%$ \\
\hline
\end{tabular}

Figure 2 showed the herders' subjective evaluation of each indicator in the two dimensions of the external environment and the impacts of PRP. According to herders' emotional attitude, the original 5-point values were divided into three categories: negative, neutral, and positive. The broken line represented the mean score of each indicator. As shown in Figure 2, the average scores of the difficulty in borrowing, relative living standard, change in income and subsidy level were less than 3 , indicating that the herders' comprehensive evaluation of these aspects was relatively negative. Specifically, the negative evaluation of difficulty in borrowing and change in income accounted for the largest proportion, and the neutral evaluation of relative living standard and subsidy level accounted for the largest proportion. The scores of natural environment, market convenience, satisfaction with government services, and ecological effects were greater than 3 , and the proportions of herders holding a positive evaluation of these aspects were much higher than that of negative and neutral evaluation. The above results show that the majority of herders were satisfied with the local natural conditions, even if the climate indicators show it was very bad. There was little difference in the perception of rich and poor among local herders, and more than half of herders believed that their living conditions were at a medium level. Many herders had some difficulties in borrowing money or getting a loan, which may affect their ability to resist risks. The local market environment was good, and it was not very difficult for herders to participate in market activities. The PRP had an obvious negative impact on the income of herders, but the subsidies had well offset some of the losses. Herders had a very positive evaluation of the government services and the effect of PRP on grassland restoration. 
120

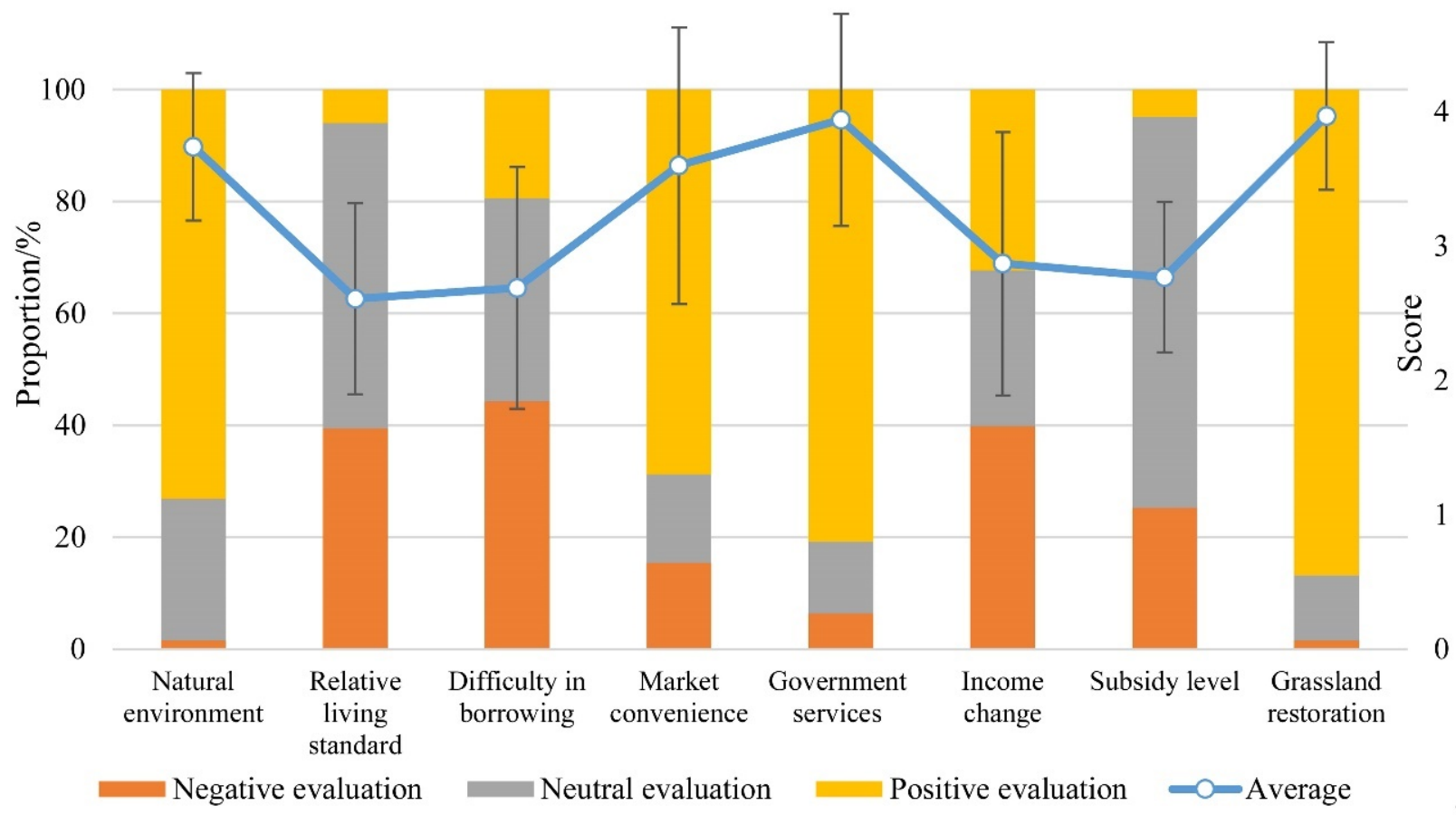

Figure 2. Herders' perception of environment and PRP's impact.

\subsection{Descriptive Analysis of Herders' Satisfaction}

The proportion of respondents' satisfaction scores of 1-5 in all areas of life was presented in Figure 3, and the black triangle represented the average of satisfaction scores. It can be seen that herders had high satisfaction about several fields of life and overall life satisfaction, with all average values greater than 3 . Among them, the satisfaction about neighborhood relations, leisure life, and work was the top three, and the overall life satisfaction was less than that of any single field. Since life satisfaction is a comprehensive assessment of personal status, high satisfaction in a certain field may be offset by low satisfaction in a certain field [42]; therefore, the overall low life satisfaction of herders indicates that some fields with low satisfaction may not be paid attention to.

The Pearson correlation matrix analysis of each variable shows that the overall satisfaction was significantly correlated with other fields' satisfaction at the level of 0.01 or 0.05 except neighborhood relationship. In order to understand the contribution of satisfaction in various fields to overall life satisfaction, SPSS software was used to carry out multiple liner regression, and the step-by-step method was used to screen variables and construct the model. In the end, only consumption satisfaction and leisure satisfaction were selected into the optimal model, with coefficients of $0.273,0.253$ respectively, indicating that compared with other variables, these two variables had a greater impact on overall life satisfaction. However, $\mathrm{R}^{2}$ of the model was 0.165 , meaning that the two variables had a relatively low interpretation of overall life satisfaction.

\subsection{Analysis of Determinants of Life Satisfaction}

Because both independent variables and dependent variables were ordered classification variables, $\chi^{2}$ test was used to judge whether each independent variable was associated with life satisfaction. Because the theoretical frequency of some levels in different independent variables were less than 1, we referred to the results of Fisher's exact test. The results (shown in Table 4) show that except for occupation, health status, whether grazing or not, and annual family income, other variables were significant at the level of 0.05 or 0.01 , indicating that these variables were related to life satisfaction. However, only according to the results of $\chi^{2}$ test, the joint impact of multiple independent variables on life satisfaction and 
the contribution of each variable cannot be judged, and multivariable regression analysis needs to be further conducted.

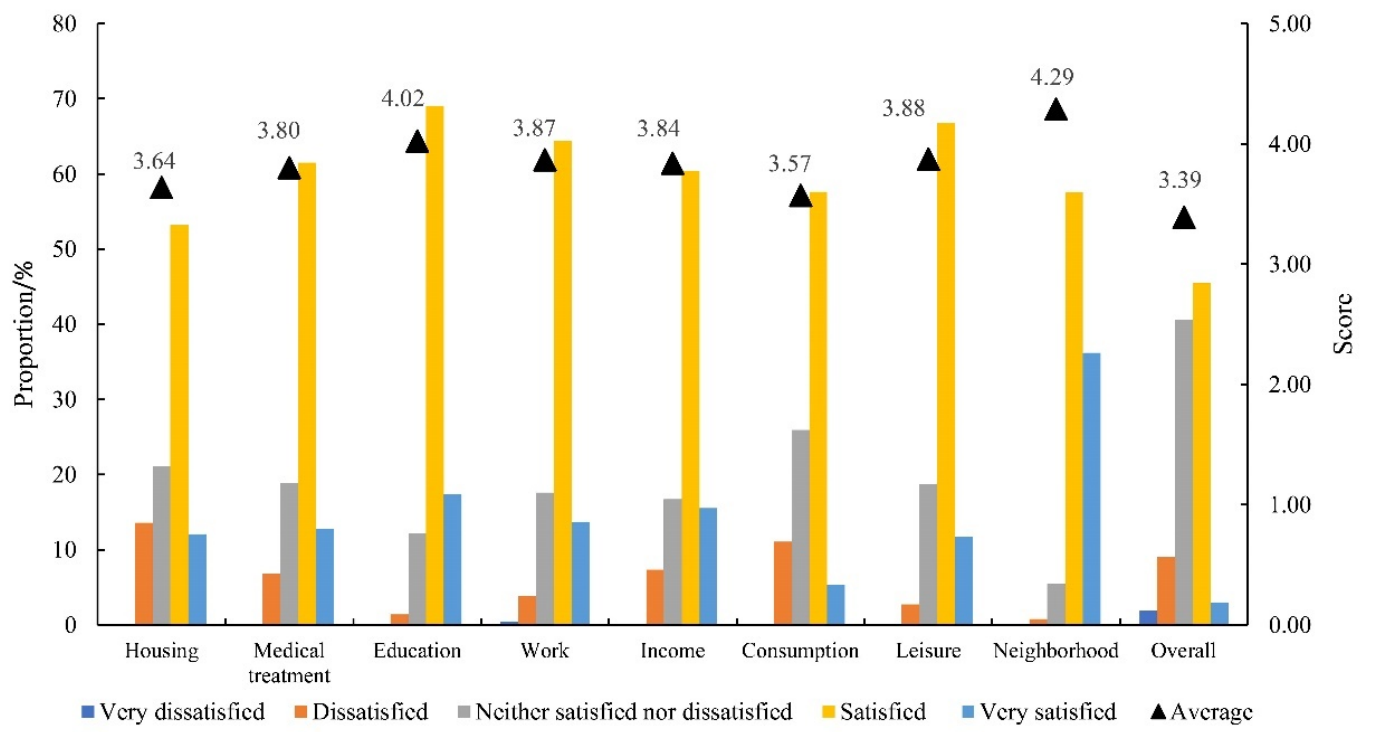

Figure 3. Herders' subjective evaluation of life satisfaction.

Table 4. Results of $\chi^{2}$ test.

\begin{tabular}{llllll}
\hline Variable Name & Fisher's Exact Test & $p$ Value & Variable Name & Fisher's Exact Test & $p$ Value \\
\hline Personal characteristics & & & Perception of the environment & & \\
Gender & 9.850 & 0.038 & Natural environment & 44.518 & 0.000 \\
Education & 29.857 & 0.007 & Difficulty in borrowing & 28.903 & 0.009 \\
Occupation & 12.215 & 0.104 & Relative living standard & 48.559 & 0.000 \\
Willingness to change & 28.163 & 0.012 & Market convenience & 41.379 & 0.000 \\
Family characteristics & & & Government services & 21.288 & 0.000 \\
Health & 20.858 & 0.093 & Impact of PRP & & 23.271 \\
Livestock retention & 6.759 & 0.110 & Immigration & 46.797 & 0.001 \\
Annual income & 11.628 & 0.401 & Income change & 51.379 & 0.000 \\
& & & Subsidy level & 26.559 & 0.000 \\
& & & Grassland restoration & 0.003 &
\end{tabular}

The optimal scale regression of different dimensional independent variables to life satisfaction was carried out separately. Table 5 showed the results of the four models, including the coefficients and significance of independent variables, the relative importance of variables, the significance of the models and $R^{2}$. The characteristic of optimal scale model is to convert the original values and construct the model with the converted values to achieve the optimal fitting effect. The influence difference of different levels of an independent variable on the dependent variable could be expressed by the product of the difference between two values and the coefficient of corresponding variable. In order to judge the difference in the impact of different levels of independent variables on life satisfaction, the converted values of independent variables with significant coefficients at the level of 0.1 were drawn in Figure 4 according to the results in Table 5. 
Table 5. Results of optimal scale regression.

\begin{tabular}{|c|c|c|c|c|c|c|c|c|}
\hline \multirow{2}{*}{ Variable Name } & \multicolumn{2}{|c|}{ Model 1} & \multicolumn{2}{|c|}{ Model 2} & \multicolumn{2}{|c|}{ Model 3} & \multicolumn{2}{|c|}{ Model 4} \\
\hline & Coefficient & Importance & Coefficient & Importance & Coefficient & Importance & Coefficient & Importance \\
\hline \multicolumn{9}{|c|}{ Personal characteristics } \\
\hline Gender & 0.079 & 0.044 & & & 0.002 & 0.000 & 0.033 & 0.000 \\
\hline Age & 0.009 & 0.001 & & & 0.024 & 0.003 & 0.059 & 0.005 \\
\hline Education & $0.202 * * *$ & 0.335 & & & 0.083 & 0.006 & 0.078 & 0.006 \\
\hline Occupation & $0.140 * *$ & 0.104 & & & $0.107^{* *}$ & 0.033 & $0.092 *$ & 0.012 \\
\hline $\begin{array}{l}\text { Willingness to } \\
\text { change }\end{array}$ & $-0.214^{* *}$ & 0.367 & & & -0.150 & 0.064 & -0.144 & 0.048 \\
\hline \multicolumn{9}{|l|}{$\begin{array}{l}\text { Family } \\
\text { characteristics }\end{array}$} \\
\hline Health & 0.026 & 0.005 & & & -0.018 & -0.001 & -0.023 & -0.004 \\
\hline $\begin{array}{l}\text { Livestock } \\
\text { retention }\end{array}$ & 0.046 & 0.021 & & & 0.098 * & 0.038 & $0.079 *$ & -0.023 \\
\hline Annual income & 0.120 & 0.123 & & & 0.099 & 0.040 & 0.067 & 0.022 \\
\hline \multicolumn{9}{|c|}{ Perception of the environment } \\
\hline \multicolumn{3}{|c|}{ Natural environment } & 0.139 & 0.076 & 0.121 & 0.083 & 0.147 & 0.074 \\
\hline \multicolumn{3}{|c|}{ Relative living standard } & $0.240^{* *}$ & 0.175 & $0.187^{* * *}$ & 0.158 & $0.146^{* *}$ & 0.084 \\
\hline \multicolumn{3}{|c|}{ Difficulty in borrowing } & $0.139^{* * *}$ & 0.077 & $0.145^{* *}$ & 0.086 & $0.148^{* * *}$ & 0.060 \\
\hline \multicolumn{3}{|l|}{$\begin{array}{l}\text { Market } \\
\text { convenience }\end{array}$} & $-0.226^{* * *}$ & 0.126 & $-0.289^{* * *}$ & 0.181 & $-0.279 * * *$ & 0.143 \\
\hline \multicolumn{3}{|l|}{$\begin{array}{l}\text { Government } \\
\text { services }\end{array}$} & $0.266^{* *}$ & 0.200 & $0.346^{* * *}$ & 0.310 & $0.284^{* * *}$ & 0.183 \\
\hline \multicolumn{9}{|l|}{ Impact of PRP } \\
\hline \multirow{2}{*}{\multicolumn{3}{|c|}{$\begin{array}{l}\text { Immigration } \\
\text { Income change }\end{array}$}} & $0.103^{* *}$ & 0.035 & & & $0.134 *$ & 0.045 \\
\hline & & & 0.223 & 0.130 & & & 0.224 & 0.124 \\
\hline \multicolumn{3}{|l|}{ Subsidy level } & -0.291 & 0.154 & & & -0.273 & 0.159 \\
\hline \multicolumn{3}{|l|}{$\begin{array}{l}\text { Grassland } \\
\text { restoration }\end{array}$} & 0.069 & 0.027 & & & 0.047 & 0.016 \\
\hline F test & 2.191 & & 7.995 & & 5.175 & & 5.646 & \\
\hline$p$ value & 0.005 & & 0.000 & & 0.000 & & 0.000 & \\
\hline$R^{2}$ & 0.133 & & 0.432 & & 0.363 & & 0.465 & \\
\hline Adjusted $\mathrm{R}^{2}$ & 0.072 & & 0.378 & & 0.293 & & 0.383 & \\
\hline
\end{tabular}

${ }^{*}, p<0.1 ; * *, p<0.05 ;{ }^{* * *}, p<0.01$.
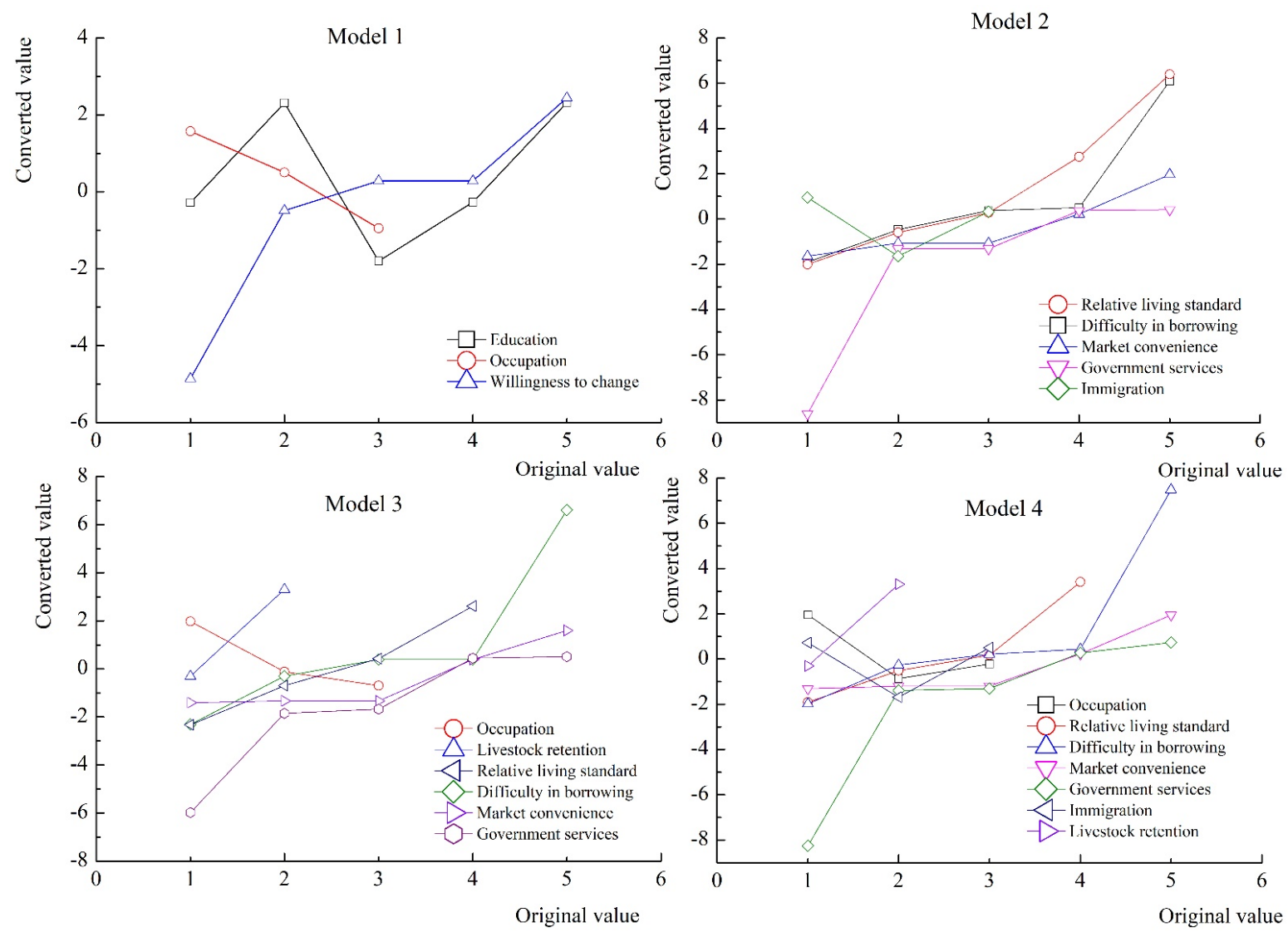

Figure 4. Numerical conversion of significant independent variables.

The results showed that the $p$ values of the four models were less than 0.01 , indicating that all models were statistically significant. The tolerance of all independent variables 
was greater than 0.1 , indicating that there was no multicollinearity between independent variables. Model 4 included all variables, with an $\mathrm{R}^{2}$ of 0.465 , indicating that the equation fitted according to selected independent variables can explain $46.5 \%$ of the variance of life satisfaction. Model 1 only included variables of individual and family characteristics, with an $R^{2}$ of 0.133 . Model 2 included variables of herders' perception of environment and the impact of PRP, for which $R^{2}$ was 0.432 . In Model 1, three variables (education, occupation, and willingness to change) were significant, but after adding other variables in Model 3 and Model 4, education and willingness to change became insignificant, and the standardized regression coefficient of occupation decreased, although it remained significant. Compared with Model 3, after adding the variables of the impact of PRP, the $\mathrm{R}^{2}$ of Model 4 only increased by 0.102 , and only the variable of immigration was significant. The above results showed that in the four dimensions, the herders' perception of the external environment had the greatest impact on life satisfaction. To improve herders' life satisfaction, the social environment in which the herders live should be optimized.

\subsubsection{Personal and Family Characteristics}

Some studies have confirmed that the relationship between demographic variables and life satisfaction was weak [41]. In our study, the significance of independent variables of individual and family characteristics changed in different models, and the explanation of these characteristics to life satisfaction decreased with the addition of more variables. In Model 1, education, occupation and willingness to change had a significant impact on life satisfaction. For every unit of education improvement, life satisfaction will increase by 0.202 units. Combined with the conversion value, herders with primary school education and college education both had higher life satisfaction. After numerical conversion, the coefficient of occupation was 0.140 , indicating that unemployed herders had the highest life satisfaction, followed by self-employment, public welfare position. According to the actual situation in Maduo County, the high satisfaction of unemployed herders may be due to the fact that their livelihoods can be maintained by subsidies and a lot of leisure time could be spent even they are incompetent for work or do not want to be employed. Pubic welfare position mainly refers to ecological managers. The reason for their low satisfaction may be that, on the one hand, the selected ecological managers inherently have relatively difficult family conditions. On the other hand, although there is a salary of about CNY 20 thousand a year, the work of frequent patrols is relatively heavy, especially for these managers who live in remote settlements. There was a negative correlation between willingness to change and life satisfaction. Life satisfaction decreased by 0.214 units when willingness to change increased by one unit, which suggests that dissatisfaction with reality may stimulate herders to make some changes. In Model 3 and Model 4, livestock retention became new positive significant factors at the level of 0.1 , showing that herders with livestock were more satisfied with their lives.

\subsubsection{Perception of Natural and Social Environment}

In the dimension of environmental perception, the natural environment had no significant impact on the herders' life satisfaction, while all variables about social environment had a significant impact in each model and the coefficients of all variables were positive except market convenience. The higher the relative living standard, the higher the life satisfaction. Combined with the conversion value in model 3, the life satisfaction of herders in the middle class and upper-middle class increased by 0.52 and 0.92 units, respectively, compared with the lower class. With the reduction of the difficulty in borrowing, the life satisfaction of herders gradually improved. The life satisfaction of herders who felt very easy was 1.29 units higher than that of herders who felt very difficult. Satisfaction with government services was also positively correlated with life satisfaction, indicating that improving the service level of government agencies could be an effective way to improve herders' life satisfaction. In term of market convenience, compared with herders who think it was very difficult to engage in market activities, the life satisfaction of herders who feel it 
was very convenient was reduced by 0.87 units. This may be because herders who think it was very convenient to engage in market activities might engage in short-term employment. Although such jobs can be found, their contribution in improving herders' life quality may be limited. Herders who think it was difficult to participate in market activities may be actively carrying out self-employed activities and experiencing more practical difficulties, but their personal abilities, family conditions and risk resistance capabilities generally stronger than surrounding families.

\subsubsection{The Impacts of PRP}

In Model 2 and Model 4, only the variable of immigration was significant at the level of 0.05 and 0.1 respectively. Combined with the conversion value in Model 3, the life satisfaction of different immigrant groups in descending order was transcity immigrants, local residence, and transcounty immigrants. According to our investigation, the transcity settlement, Guoluo New Village, is far away from nearby towns, and the surrounding land belongs to other towns and cannot be used. Most livestock greenhouses built at the beginning have been abandoned. Compared with other places, the livelihood development of the herders in this village should be relatively disadvantageous. However, the results show that the herders in Guoluo New Village were highly satisfied, which may be because after the earthquake, most of the residents of Guoluo New Village returned to live in tents around the Maduo county, and the proper resettlement of the government may promote the herders to make a higher life satisfaction evaluation at that time.

Many studies have suggested that the positive impact of the policies on income and the improvement of subsidy level can promote the improvement of life satisfaction [22]. From our results, compared with other variables, the effects of the two were not significant, the importance of income change, subsidy level accounted for more than $10 \%$, indicating that these two variables were more important in explaining life satisfaction than other independent variables and the greater the positive impact of income, the higher herders' life satisfaction. However, too many subsidies may have no positive effect on improving herders' life satisfaction. It could be observed that the direct impact of PRP on herders' life satisfaction might be not obvious, but the PRP could indirectly affect herders' life satisfaction through a number of measures, such as the performance of the government during the implementation of the program, the relative income level of herders after subsidy, new livelihood and social relations after resettlement, etc.

\section{Conclusions and Discussion}

This paper analyzed herders' life satisfaction and its influencing factors under the PRP in Maduo County, the source of the Yellow River. Our results suggested that the life satisfaction of herders in Maduo County was relatively high, which was largely due to the government's strong subsidies and the overall improvement of people's livelihood under the background of poverty alleviation and Sanjiangyuan National Park construction in recent years. The positive impact of PRP on the lives of herders in Maduo County has increased in recent years. At present, the subsidy level and the impact of PRP on income were no longer significant factors influencing the satisfaction of herders, although they were also very important. The gap between the rich and the poor, the level of assistance available, and the quality of government services had a greater impact on the satisfaction of herdsmen.

The difference in socioeconomic situation and government assistance in different regions will result in different impacts of the PRP on herders. The Sanjiangyuan area, especially the area where the Sanjiangyuan National Park is located, has its own characteristics, which distinguish it from other implementation areas of PRP. Firstly, the grazing prohibition area is much larger than the forage-livestock balance area, and there is no available cultivated land for herders to plant forage to feeding livestock. After the grazing prohibition, many herders moved to cities and towns and only a few herders still stayed in the grazing prohibition area. Therefore, many herders have experienced a rapid change in 
their lifestyle in a short time and can no longer continue to engage in animal husbandry. Secondly, after the migration, geographical location, employment environment and language barriers make it difficult for local herders to move to other areas for reemployment such as herders in Gansu, Ningxia, and Inner Mongolia [43]. In addition, with the change of lifestyle, herders need to spend much money on daily necessities imported from outside, such as food and fuel, and travel to more developed areas for medical treatment and education. Therefore, the immigrants are more dependent on government subsidies than other areas. Finally, although the natural and social environment is very unfavorable, the state's high subsidies and assistance to this region are also different from other regions. Now, the main source of income of herders, especially the migrants, was government cash subsidies and subsidies for public-service jobs. However, the subsidy system may not be feasible in other areas due to their lower ecological status, huge population size and availability of alternative livelihoods.

The uniqueness of each region means that the policies should be more targeted and flexible to promote the well-being of residents. The government usually focuses on promoting income growth and optimizing infrastructure to improving people's well-being. The efforts in Maduo County by optimizing infrastructure such as medical treatment, education, transportation, and electricity have received positive feedback, which is reflected in relatively high satisfaction of herders in the main aspects of life, although the objective conditions may be far inferior to other developed areas. Increasing subsidies has always been regarded as a way to ensure the well-being of local people in the implementation area of PRP [44]. However, the improvement of absolute income and life satisfaction may not keep pace $[45,46]$, which was also confirmed by our research. In Maduo County, nearly $70 \%$ of herders think the subsidy was appropriate at present. In terms of family economic conditions, the impact of relative living standards is more important than that of absolute income and income changed by PRP. In addition, the possibility of obtaining support from relatives, friends, and the government would significantly affect herders' life satisfaction. In terms of the importance of all areas of life to overall life satisfaction, consumption and leisure life had a greater impact, which is consistent with some research results [47]. These results mean that the psychological needs of local herders are more important than material needs in the overall life satisfaction. Therefore, the optimization of PRP should start by controlling the gap between the rich and the poor, optimizing social assistance channels, and improving government service level.

In addition, under the current subsidy system, herders' livelihoods have been basically guaranteed. Herders who are unemployed or do not want to change the current situation have higher life satisfaction, but the high life satisfaction maintained by subsidies may weaken herders' own development potential and ability to deal with risks in the future. Herders themselves have the motivation to make some change when they feel dissatisfied with life, but whether they can change in the end is affected by many factors. In terms of policy design, on the one hand, the original subsidies should not be reduced at the beginning of active development, which may lead to herders' fear of risks and complacency with the status quo. On the other hand, education and vocational training for herders and their next generation should be strengthened to enable them to own more opportunities for self-development, and to reduce their dependence on subsidies.

Although this article could contribute to understanding the life satisfaction of local herders, it has some limitations for policy reference. The first is that the high self-rated life satisfaction of herdsmen may not mean that the local development level and herdsmen's living standard are consistent with those in more developed areas, but may be due to the narrow reference standard of herders [48]. The second is that $53.5 \%$ of the variance in life satisfaction remained unexplained. Since there is a satisfaction baseline based on people's own characteristics [49], for policy makers, the most concern should be placed on the part that can promote life satisfaction through policy design. Our research has found the differences in life satisfaction of different types of herders, so the differences in the 
demands of families with different conditions need to be identified and more effective assistance are needed in the future.

There are still many issues worthy of further study. First, due to the numerous factors that influence life satisfaction and the uniqueness of Tibetan culture, future research can explore its impact on life satisfaction from the perspectives of herders' own personalities, comparative standards, and religious influences, etc. Second, in the future multidimensional scales with higher reliability could be used to further explore the relationship between life satisfaction and satisfaction in various fields, as well as the influencing factors of satisfaction in various fields, so as to find specific ways to improve local people's well-being. Finally, due to the particularity of Maduo County, in the future, more examples should be studied to compare the differences in the impact of policies.

Author Contributions: Conceptualization, C.X., L.Z. and Y.W.; methodology, C.X. and Y.W.; data collection, C.X., L.Z., Y.W. and X.P.; writing original draft and preparation, C.X.; data analysis, C.X. and Y.W. All authors have read and agreed to the published version of the manuscript.

Funding: This research was funded by the Second Tibetan Plateau Scientific Expedition and Research Program (2019QZKK0404), The Strategic Priority Research Program of the Chinese Academy of Sciences (XDA20020401) and Joint Grant from Chinese Academy of Sciences-People's Government of Qinghai Province on Sanjiangyuan National Park (LHZX-2020-09).

Institutional Review Board Statement: Ethical review and approval were waived for this study due to this study was not for medical purposes.

Informed Consent Statement: Informed consent was obtained from all subjects involved in the study.

Conflicts of Interest: The authors declare no conflict of interest.

\section{Appendix A. Blank Informed Consent}

Questionnaire for herders of performance evaluation of the Pastureland Rehabilitation Program in Sanjiangyuan area

Hello! We are researchers from the Institutes of Science and Development, Chinese Academy of Sciences. We are here to conduct a questionnaire survey on the impact of the Pastureland Rehabilitation Program on the herders' livelihood. This survey is completely anonymous, and we will not disclose any information about you. Please feel free to answer. Thank you very much for your support for our work.

\section{References}

1. McMahon, D.M. The pursuit of happiness in history. In The Science of Subjective Well-Being; Eid, M., Larsen, R.J., Eds.; Guilford: New York, NY, USA, 2008; pp. 80-93.

2. Salovey, P.; Mayer, J.D. Emotional intelligence. Imagin. Cogn. Personal. 1990, 9, 185-211. [CrossRef]

3. Bailey, T.C.; Eng, W.; Frisch, M.B.; Snyder, C.R. Hope and optimism as related to life satisfaction. J. Posit. Psychol. 2007, 2, 168-175. [CrossRef]

4. Diener, E.; Diner, M. Cross-Cultural Correlates of Life Satisfaction and Self-Esteem. J. Personal. Soc. Psychol. 1995, 68, 653-663. [CrossRef]

5. Pavot, W.; Diener, E. Review of the Satisfaction with Life Scale. Psychol. Assess. 1993, 5, 164-172. [CrossRef]

6. Diener, E.; Inglehart, R.F.; Tay, L. Theory and Validity of Life Satisfaction Scales. Soc. Indic. Res. 2012, 112, 497-527. [CrossRef]

7. Frey, B.S.; Stutzer, A. What can Economists Learn from Happiness Research? J. Econ. Lit. 2002, 40, 402-435. [CrossRef]

8. Londoño, C.O.; Mesa, D.G.; Cardona-Sosa, L.; Toro, C.G. Happiness and victimization in Latin America. J. Happiness Stud. 2019, 20, 935-954. [CrossRef]

9. Alexandrova, A. Subjective well-being and Kahneman's 'objective happiness'. J. Happiness Stud. 2005, 6, 301-324. [CrossRef]

10. Blanchflower, D.G.; Oswald, A.J. Well-being over time in Britain and the USA. J. Public Econ. 2004, 88, 1359-1386. [CrossRef]

11. Appleton, S.; Song, L. Life Satisfaction in Urban China: Components and Determinants. World Dev. 2008, 36, 2325-2340. [CrossRef]

12. Arrindell, W.A.; Heesink, J.; Feij, J.A. The satisfaction with life scale (SWLS): Appraisal with 1700 healthy young adults in The Netherlands. Personal. Individ. Differ. 1999, 26, 815-826. [CrossRef]

13. Ortega-Gil, M.; Cortés-Sierra, G.; ElHichou-Ahmed, C. The Effect of Environmental Degradation, Climate Change, and the European Green Deal Tools on Life Satisfaction. Energies 2021, 14, 5839. [CrossRef]

14. Mirehie, M.; Sato, S.; Krohn, B. Participation in Active Sport Tourism and Life Satisfaction: Comparing Golf, Snowboarding, and Long-Distance Running. Sustainability 2021, 13, 10316. [CrossRef] 
15. Berlemann, M.; Eurich, M. Natural hazard risk and life satisfaction-Empirical evidence for hurricanes. Ecol. Econ. 2021, 190, 107194. [CrossRef]

16. Easterlin, R.A.; Morgan, R.; Switek, M.; Wang, F. From the cover: China's life satisfaction, 1990-2010. Proc. Natl. Acad. Sci. USA 2012, 109, 9775-9780. [CrossRef] [PubMed]

17. Fan, J.; Zhong, H.; Harris, W.; Yu, G.; Wang, S.; Hu, Z.; Yue, Y. Carbon storage in the grasslands of China based on field measurements of above- and below-ground biomass. Clim. Chang. 2008, 86, 375-396. [CrossRef]

18. Hu, Y.N.; Huang, J.K.; Hou, L.L. Impacts of the Grassland Ecological Compensation Policy on Household Livestock Production in China: An Empirical Study in Inner Mongolia. Ecol. Econ. 2019, 161, 248-256. [CrossRef]

19. Hou, C.; Zhou, L.; Wen, Y.; Chen, Y. Farmers' adaptability to the policy of ecological protection in China-A case study in Yanchi County, China. Soc. Sci. J. 2018, 55, 404-412. [CrossRef]

20. Byrne, A.T.; Hadrich, J.C.; Robinson, B.E.; Han, G.D. A factor-income approach to estimating grassland protection subsidy payments to livestock herders in Inner Mongolia, China. Land Use Policy 2020, 91, 104352. [CrossRef]

21. Li, M.Y.; Zhao, P.J.; Wu, L.B.; Chen, K. Effects of Value Perception, Environmental Regulation and Their Interaction on the Improvement of Herdsmen's Grassland Ecological Policy Satisfaction. Int. J. Environ. Res. Public Health 2021, 18, 3078. [CrossRef]

22. Wang, L.; Liu, X. Satisfaction with grassland eco-compensation policies for herders: An empirical study on the Gansu Pastoral Area. Acta Ecol. Sin. 2017, 37, 5798-5806. (In Chinese)

23. Johnson, D.C.S.M. Avowed happiness as an overall assessment of the quality of life. Soc. Indic. Res. 1978, 5, 475-492. [CrossRef]

24. Diener, E.; Suh, E.M.; Lucas, R.E.; Smith, H.L. Subjective well-being: Three decades of progress. Psychol. Bull. 1999, 125, 276-302. [CrossRef]

25. Helliwell, J.F. How's life? Combining individual and national variables to explain subjective well-being. Econ. Model. 2003, 20,331-360. [CrossRef]

26. Diener, E.; Oishi, S.; Tay, L. Advances in subjective well-being research. Nat. Hum. Behav. 2018, 2, 253-260. [CrossRef] [PubMed]

27. Diener, E.; Oishi, S.; Lucas, R.E. Subjective well-being: The science of happiness and life satisfaction. In Oxford Handbook of Positive Psychology; Snyder, C.R., Lopez, S.J., Edwards, L.M., Marques, S.C., Eds.; Oxford University Press: Oxford, UK, 2009 ; pp. 187-194.

28. Maslow, A.H. Motivation and Personality; Harper \& Row: New York, NY, USA, 1970.

29. Michalos, A.C. Multiple discrepancies theory. Soc. Indic. Res. 1985, 16, 347-413. [CrossRef]

30. Shields, M.A.; Price, S.W.; Wooden, M. Life satisfaction and the economic and social characteristics of neighbourhoods. J. Popul. Econ. 2009, 22, 421-443. [CrossRef]

31. Yin, Y.T.; Hou, Y.L.; Langford, C.; Bai, H.H.; Hou, X.Y. Herder stocking rate and household income under the Grassland Ecological Protection Award Policy in northern China. Land Use Policy 2019, 82, 120-129. [CrossRef]

32. Yu, Y.; Wu, Y.; Wang, P.; Zhang, Y.L.; Yang, L.E.; Cheng, X.; Yan, J.Z. Grassland Subsidies Increase the Number of Livestock on the Tibetan Plateau: Why Does the "Payment for Ecosystem Services" Policy Have the Opposite Outcome? Sustainability 2021, 13, 6208. [CrossRef]

33. Wang, Y.; Han, Y.Q.; Han, Y.J.; Li, W.C. Does the grassland ecological compensation policy improve the herders' breeding technical efficiency in china?-based on the parallel mediation effect model. PLoS ONE 2021, 16, e0249990. [CrossRef]

34. Liu, M.; Rao, D.; Yang, L.; Min, Q. Subsidy, training or material supply? The impact path of eco-compensation method on farmers livelihood assets. J. Environ. Manag. 2021, 287, 112339. [CrossRef] [PubMed]

35. Zhen, L.; Li, F.; Yan, H.M.; Liu, G.H.; Liu, J.Y.; Zhang, H.Y.; Du, B.Z.; Wu, R.Z.; Sun, C.Z.; Wang, C. Herders' willingness to accept versus the public sector's willingness to pay for grassland restoration in the Xilingol League of Inner Mongolia, China. Environ. Res. Lett. 2014, 9, 045003. [CrossRef]

36. Ding, R.; Shao, L.Q.; Chen, H.B. Curbing overstocking on rangeland through subsidies, rewards, and herders' social capital: Lessons from Qinghai province, China. J. Rural. Stud. 2021, 87, 361-374. [CrossRef]

37. Wang, W.; Zhou, L.; Yang, G.; Sun, Y.; Chen, Y. Prohibited grazing policy satisfaction and life satisfaction in rural northwest China-a case study in Yanchi County, Ningxia Hui Autonomous Region. Int. J. Environ. Res. Public Health 2019, $16,4374$. [CrossRef]

38. Li, Y.; Wei, T.; Jin, L. Herdspeople Attitudes Towards Grassland Eco- Compensation Policies in Siziwang Banner, Inner Mongolia. Resour. Sci. 2014, 36, 2442-2450. (In Chinese)

39. Wang, W.; Yang, G.; Sun, Y.; Chen, Y.; Zhou, L. Linking prohibited grazing policy to farmers' subjective well-being: A case study in Yanchi County, China. Sustainability 2019, 11, 2180. [CrossRef]

40. Zhang, Z.L.; Xiang, F. Analysis of population and economy of Maduo County in the source area of the Yellow River. Popul. Res. 1985, 1, 46-49. (In Chinese)

41. Piko, B.F.; Hamvai, C. Parent, school and peer-related correlates of adolescents' life satisfaction. Child. Youth Serv. Rev. 2010, 32, 1479-1482. [CrossRef]

42. Binder, M.; Coad, A. Life satisfaction and self-employment: A matching approach. Small Bus. Econ. 2013, 40, 1009-1033. [CrossRef]

43. Du, B.; Zhen, L.; Yan, H.; De Groot, R. Effects of Government Grassland Conservation Policy on Household Livelihoods and Dependence on Local Grasslands: Evidence from Inner Mongolia, China. Sustainability 2016, 8, 1314. [CrossRef]

44. Gao, L.; Kinnucan, H.W.; Zhang, Y.; Qiao, G. The effects of a subsidy for grassland protection on livestock numbers, grazing intensity, and herders' income in inner Mongolia. Land Use Policy 2016, 54, 302-312. [CrossRef] 
45. Akay, A.; Martinsson, P.J.E.L. Does relative income matter for the very poor? Evidence from rural Ethiopia. Econ. Lett. 2008, 110, 213-215. [CrossRef]

46. Muresan, G.M.; Ciumas, C.; Achim, M.V. Can money buy happiness? Evidence for European countries. Appl. Res. Qual. Life 2020, 15, 953-970. [CrossRef]

47. Leisure and Life Satisfaction: Foundational Perspectives; Ginton, C.R. (Ed.) WCB/McGraw-Hill Press: New York, NY, USA, 1995.

48. Knight, J.; Lina, S.O.N.G.; Gunatilaka, R. Subjective well-being and its determinants in rural China. China Econ. Rev. 2009, 20, 635-649. [CrossRef]

49. Fujita, F.; Diener, E. Life satisfaction set point: Stability and change. J. Personal. Soc. Psychol. 2005, 88, 158-164. [CrossRef] 